\title{
THE USAGE OF GROUND-COUPLED HEAT EXCHANGERS IN SUBTROPICAL CLIMATES
}

\begin{abstract}
This study aims to identify the feasibility of using a ground-coupled heat exchanger system for air conditioning in subtropical regions. Geothermal systems are used effectively in cold climates, but little explored in hot and humid climate regions, although they show potential for passive air-conditioning environments. The tubes were installed in Southern Brazil, in Foz do Iguaçu, Paraná, which has temperatures of $0^{\circ} \mathrm{C}$ in the winter and $40^{\circ} \mathrm{C}$ in the summer. The methodology for the research was organized as follows: bibliographic research and geological characterization of the site, system sizing, installation of 22 meters of a 300mm PVC tube, 4 meters depth, and subsequently measurement and data collection on temperatures with use HOBO U10-001 Data Logger. The research was held from March to October 2016. The results showed that at external temperatures of $30^{\circ} \mathrm{C}$, the system was able to cool on average $6^{\circ} \mathrm{C}$, reaching peaks of $7^{\circ} \mathrm{C}$ in the temperature of air exit to the environment. At temperatures below $6^{\circ} \mathrm{C}$, the system was able to heat on average $10^{\circ} \mathrm{C}$, with peaks of up to $11^{\circ} \mathrm{C}$. Based on the results, it is concluded that a buried pipe system is a viable alternative for passive climate control in subtropical climates
\end{abstract}

\section{Introduction}

The research of ground-coupled heat exchangers gain attention in the scientific environment due to the possibility of energy efficiency with the reduction of the consumption of energy for air conditioning and the increase in the air quality for indoor areas.

The high level of energy consumption in the world is a major issue to be solved and the construction sector accounts for $40 \%$ of the world's energy consumption [1].

It is known that the period of use of facilities represents about $84 \%$ of the total energy consumption of its life cycle (Buried-pipe Ventilation Systems), being the one which lasts longer. Air conditioning is responsible for a large part of this percentage.

\section{Proposal objectives and justification}

According to the National Energy Balance of 2018 (base year of 2017) of the Ministry of Mines and Energy of Brazil [2] electricity consumption of residential, commercial and public buildings, in Brazil, corresponds to $50.8 \%$ of the total energy consumption of the country and the use of air conditioning in 2017 accounted for $20 \%$ of the total energy consumption of a residence in the country [3].

In this way, Lamberts, Dutra and Pereira [3], claim that the best strategy for the scenario presented is the efficient use of energy resources through energy efficiency, providing users with thermal, light and acoustic comfort with low energy consumption, since saving energy is cheaper than providing it.

Under this context, in the quest to relieve the environmental impact and promote economy in the energy consumption, different passive strategies have been developed and applied in the building all around the world. [4], states that natural ventilation is the second best bioclimatic strategy to be used in tropical climates.
In hot climate regions with high humidity rates, natural ventilation does not meet the demand for acclimatization when the outside air has a temperature above 32 degrees Celsius given to the fact that warm and dense air does not provide comfort to the user.

Therefore, it may be necessary to use additional techniques of environmental comfort. Among the existing options are: the creation of an external microclimate that preheats the air, creating a microclimate with vegetation and natural sources such as stones and shaded water so that air is conditioned before entering the windows; and geothermal systems consisting of buried pipes that cool air down before entering the residence by changing the temperature with the earth.

This is a widespread strategy in developed countries, but little operated in Brazil. Geothermics benefits from the milder soil temperature to preheat or pre-cool the air that is directed to the interior of the building in order to bring the temperature closer to the environment temperature, creating better conditions of thermal comfort for the user.

In addition, Lengen [5] states that, as it does not require energy sources, easy to install and is adaptable to basically any terrain, it is expected that the system become assimilated by poorer classes [6].

The present article aims to study the feasibility of the use of the heat-pipe heater system of air-to-air type in regions of hot and humid subtropical climate.

\section{Literature review}

The purpose of such review is not to exhaust the theme but to explore concepts and definitions about the topic.

The humid subtropical climate is characterized by the transition from the tropical to the temperate climate and it affects Southern Brazil, with a daytime temperature ranging from $26^{\circ}$ to $35^{\circ} \mathrm{C}$ [4]. 
Passive architecture design in tropical climates differs from dry and humid climates, since the high temperature combined with high humidity creates conditions outside the comfort zone and makes the cooling of the body by perspiration difficult. According to [4] the best strategies for hot and humid climates are, in order, the shading of façades that receive solar radiation followed by natural day and night ventilation.

Ground-coupled heat exchangers - earth to air - that make use of geothermal energy are presented as an alternative in reducing energy consumption from non-renewable sources in the climate of the environment. It is estimated that in 2010 , 78 countries made direct use of geothermal energy [7].

There are different passive acclimatization systems and due to their capacity to produce cooling in the hot seasons and heating in the cold seasons, one of the most used for their efficiency potential is the EAHE Earth-to-Air Heat Exchangers [7] [8].

This system is characterized by preheating or pre-cooling the air by using a fan that moves air through the tubes buried in the ground. Heat transfer occurs by convection of the air into the tube and from the tube to the ground [7].

The sizing of the system is in accordance with the internal environment acclimatization demands. One end of the system is attached to the external air collector equipment and the other to the environment. The collected air loses heat according to the temperature change between the pipe walls and the floor so that when entering the room, the air temperature is reduced and close to room temperature. The air heating process occurs similarly [9].

Throughout the day the soil is heated by solar radiation, and at night, it gives energy to the atmosphere, acting as a thermal stabilizer. The soil behaves like a reservoir with great thermal inertia [10] so that the thermal amplitude is attenuated exponentially according to the depth [9].

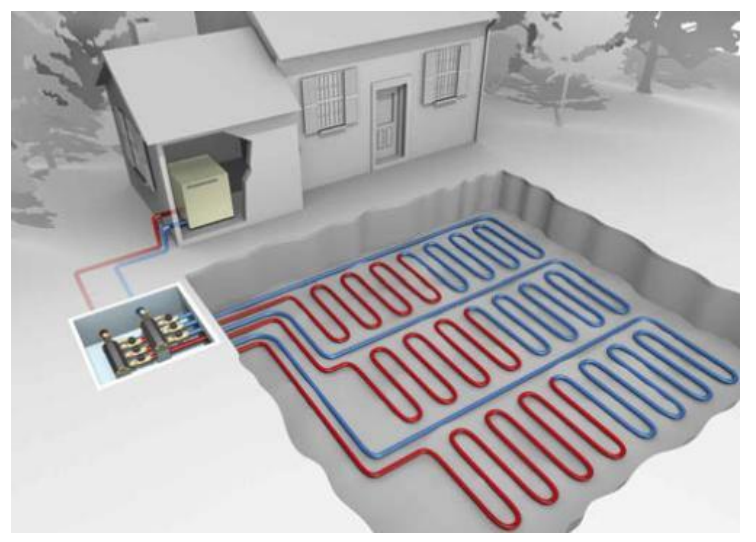

Fig. 1. Horizontal and shallow geothermal system.

The EAHE system can still be classified according to the installation depth. The horizontal or shallow system is characterized by its installation from 1 to 4 meters deep. The external air enters the buried tube where the heat exchange with the soil occurs and the reduction of its temperature. The greatest advantage of this system is the affordable cost, due to lower depth drilling, and in relation to the disadvantages, the greatest susceptibility to air contamination due to moisture is present, and at this depth temperatures tend to present greater variation [11].
Austria, Germany and Switzerland are the places where the use of superficial geothermics has taken place more extensively with about 50 thousand buildings with this type of system installed [12].

Regarding the vertical or deep system, heat rejection occurs in the soil. The disadvantage is the high cost of installation, due to the depth of drilling and for advantages, it demands smaller area of land for its installation, besides greater stability in the temperature given to the depth it is installed.

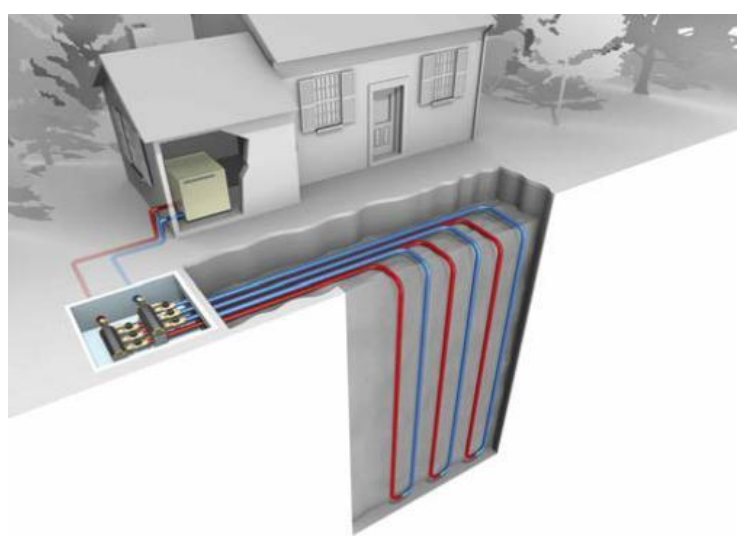

Fig. 2. Vertical and deep geothermal system.

The geothermal heat exchanger system can be affected by different elements, such as the material of the pipes, the fan power chosen, the local soil characteristics, the local climate and the type of system. The material of the tubes must be defined according to the context of the system taking into consideration aspects such as course, durability and resistance to corrosion [13].

Geothermal heat exchangers can still be classified as open or closed loop. The success of the open loop systems is directly influenced by the external air temperature as in regions with very high and very low temperatures, the effectiveness of the system tends to reduce due to the outlet air temperature of the system being coupled to the external temperature, with some degrees of difference to more or less, according to the season [7].

In this regard, in the case of closed loop systems, the use of fluid to maintain the temperature, called Groun-Culed Heat Pumps (GCHPs), according to ASHRAE - American Society of Heating, Refrigerating and AC Engineers Fdn (2001) despite using electric energy by the aid of heat pumps, they point to a reduction of about $30 \%$ in energy consumption compared to traditional artificial systems [14].

The largest geothermal heating system was installed in Rykjvavik, Iceland in 1930. It is a closed system that uses natural warm water from hot springs to heat the internal air of buildings. These systems have gained scale of installation in homes after World War II [11].

It is possible to identify that the geothermal system is quite widespread in developed countries, where systems are installed from homes to large buildings, such as Nike headquarters building in Hilversum in the Netherlands and Oslo airport in Norway [11].

It is also noticed that oil crises in the course of history and the Kyoto Protocol have boosted development in the advance of researches on the geothermal systems, as a way to 
guarantee affordable acclimatization for populations, as it is the case of Pacífico subway station, in Madrid, Spain, which was the first one capable of generating its own energy for acclimatization using geothermal energy [11].

\section{Methodology}

The methodology was design according to the steps for the development of the system: geological characterization with survey collection on the local soil to support the sizing and system design, computer simulation with the purpose of predicting scenarios, installation of the system in loco and data collection.

\subsection{Geological characterization}

In compliance with a simulation carried out through Climate Consultant 6.0 BETA version software, the soil temperature in Foz do Iguaçu at a 2-meter depth reaches a maximum of $27^{\circ} \mathrm{C}$ during the summer and a minimum of $17^{\circ} \mathrm{C}$ in the winter. The temperature has even more stability in a 4-meter depth, with peaks of $24^{\circ} \mathrm{C}$ in summer and $18^{\circ} \mathrm{C}$ in winter.

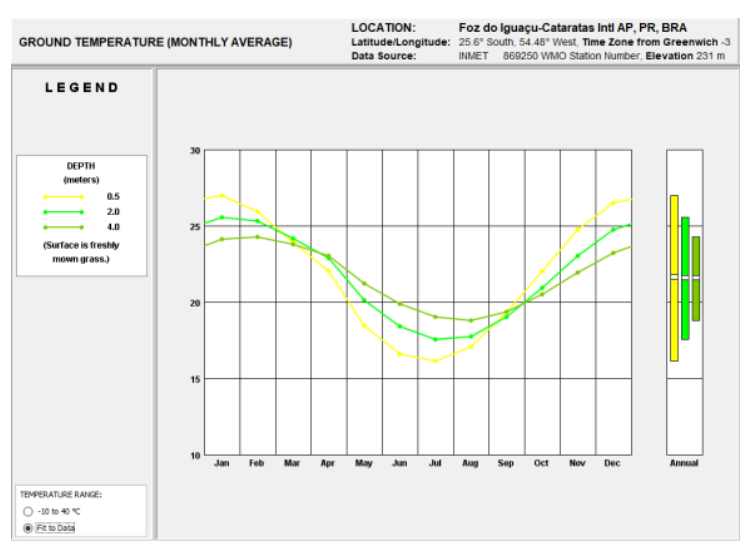

Fig. 3. Soil temperature in Foz do Iguacu.

The first aspect to be identified, and the most limiting one, is the thermal conductivity of the soil. This data determined the design of the system. To obtain the data, the table in the ASHRAE 2007 manual was used, which presents density, conductivity and thermal diffusivity for each type of soil [9].

Table 1. Selected soils, rocks and grouts / landfills thermal properties.

\begin{tabular}{|c|c|c|c|}
\hline & $\begin{array}{c}\text { Dry } \\
\text { density } \\
{\left[\mathbf{k g} / \mathbf{m}^{3}\right]}\end{array}$ & $\begin{array}{c}\text { Conductivity } \\
{[\mathbf{W} / \mathbf{m} . \mathbf{K}]}\end{array}$ & $\begin{array}{c}\text { Diffusivity } \\
{[\mathbf{x 1 0 - 7}} \\
\left.\mathbf{m}^{2} / \mathbf{S}\right]\end{array}$ \\
\hline Soils type \\
\hline $\begin{array}{c}\text { Heavy earth, } 15 \% \\
\text { water }\end{array}$ & 1925 & 1,4 a 1,9 & 4,86 a 7,06 \\
\hline
\end{tabular}

\begin{tabular}{|c|c|c|c|}
\hline Heavy earth, $5 \%$ water & 1925 & 1,0 a 1,4 & 5,44 a 7,06 \\
\hline Light earth, $15 \%$ water & 1285 & 0,7 a 1,0 & 6,36 a 5,44 \\
\hline Light earth, $15 \%$ water & 1285 & 0,5 a 0,9 & 6,48 a 6,48 \\
\hline $\begin{array}{l}\text { Heavy sand, } 15 \% \\
\text { water }\end{array}$ & 1925 & 2,8 a 3,8 & 9,72 a 12,73 \\
\hline Heavy sand, $5 \%$ water & 1925 & 2,1 a 2,3 & $\begin{array}{c}10,76 \mathrm{a} \\
16,20\end{array}$ \\
\hline Light sand, $15 \%$ water & 1285 & 1,0 a 2,1 & 5,44 a 10,71 \\
\hline Light sand, $5 \%$ water & 1285 & 0,9 a 1,9 & 6,33 a 11,38 \\
\hline \multicolumn{4}{|l|}{ Rocks } \\
\hline Granite & 2650 & 2,3 a 3,7 & 9,72 a 15,05 \\
\hline Limestone & $\begin{array}{c}2400 \mathrm{a} \\
2800\end{array}$ & 2,4 a 3,8 & 9,72 a 15,05 \\
\hline Sandstone & $\begin{array}{c}2570 \mathrm{a} \\
2730\end{array}$ & 2,1 a 3,5 & $\begin{array}{c}75,20 \mathrm{a} \\
12,73\end{array}$ \\
\hline
\end{tabular}

As the local soil was considered heavy with $15 \%$ water, the conductivity of $1.9 \mathrm{~W} / \mathrm{m} . \mathrm{K}$ was determined. For the sequence of the development of the system, according to the research, we established the depth of 4 meters given to the lower temperature variation identified in the simulation.

\subsection{Sizing}

It was used an Excel table available at http://www.puitscanadien.com/index.php/theorie/telecharge ment/ for piping sizing which also offers some other tools for the sizing of shallow geothermal acclimatization systems.

The table is divided into cubic size of air required within the room; renewal of ambient air per hour; diameter, thickness and tube conductivity; air and soil temperature parameters; calculation memory and the result of the theoretical length of the tube.

The result presented by the table for $280 \mathrm{~m}^{3}$ of every 20 minutes changed air with $300 \mathrm{~mm}$ PVC pipes with a $2 \mathrm{~mm}$ wall was 19.51 linear meters.

To confirm the table data CFD computer simulations were done on Solidworks software by Dassault Systèmes SA.

\subsection{Computer simulation}

The simulation was developed by SolidWorks software, which performs data analysis by finite calculations. For simulation the following guidelines were adopted:

Scenario 01: Modeling of 21-meter PVC tubes with $300 \mathrm{~mm}$ diameters and soil conductivity influence of 1.9 $\mathrm{W} / \mathrm{m} . \mathrm{K}$ at an average temperature of $19.5^{\circ} \mathrm{C}$; Air inlet at a temperature of $35^{\circ} \mathrm{C}$ being inflated to $0.5 \mathrm{~m} / \mathrm{s}$; At the outlet of the duct an exhaust flow with $6 \mathrm{~m}^{3}$ suction flow of air. 


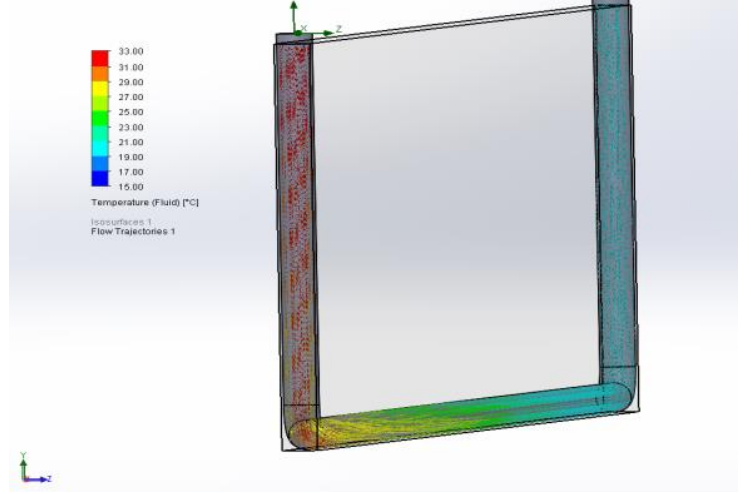

Fig. 4. Scenario 01 simulation.

Scenario 02: Modeling of 21-meter PVC tubes with $300 \mathrm{~mm}$ diameters and influence of soil conductivity of $1.9 \mathrm{~W} / \mathrm{m} . \mathrm{K}$ at an average temperature of $19.5^{\circ} \mathrm{C}$; Air inlet at a temperature of $5^{\circ} \mathrm{C}$ being inflated to $0.5 \mathrm{~m} / \mathrm{s}$; At the outlet of the duct an exhaust flow with $6 \mathrm{~m}^{3}$ suction flow of air.
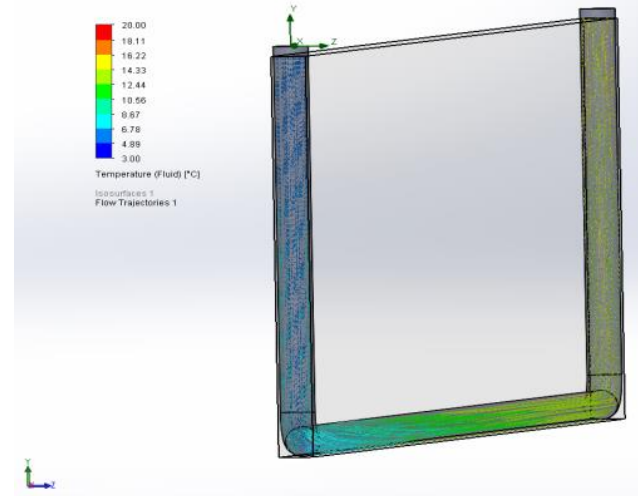

Fig. 5. Scenario 02 simulation.

\subsection{System installation}

For the installation of the system, the following steps were performed:

1. Delineation of the site to be dug;

2. Digging using a backhoe for 2 hours;

3. Sand pouring for leveling and adjustment of vertical concrete pipes helped by backhoes and two helpers. Adjustment must be carried out on the same days as to avoid risk of collapse;

4. Pruning of vertical tubes and cutting for fitting of PVC pipes;

5. Descending of PVC pipes.

6. Mounting of PVC pipes with tools:

a. Makita power tool for cutting the tube;

b. 5 pipes of 6-meter long +2 PVC knees of $300 \mathrm{~mm}$ with wall of $3 \mathrm{~mm}$;

c. 2 sandpapers of 80 ;

d. 1 tube of glue of $500 \mathrm{ml}$;

e. Hammer

Leveling of ducts with $1 \%$ inclination and welding of PVC ducts with vertical concrete ducts.

7. Leveling of ducts with $1 \%$ inclination and welding of PVC ducts with vertical concrete ducts;
8. Filling the gaps with $80 \mathrm{~cm}$ coarse sand, total of $30 \mathrm{~m}^{3}$ of sand;

9. Ducts closing with concrete cover;

10. 6 months of rest and land consolidation.

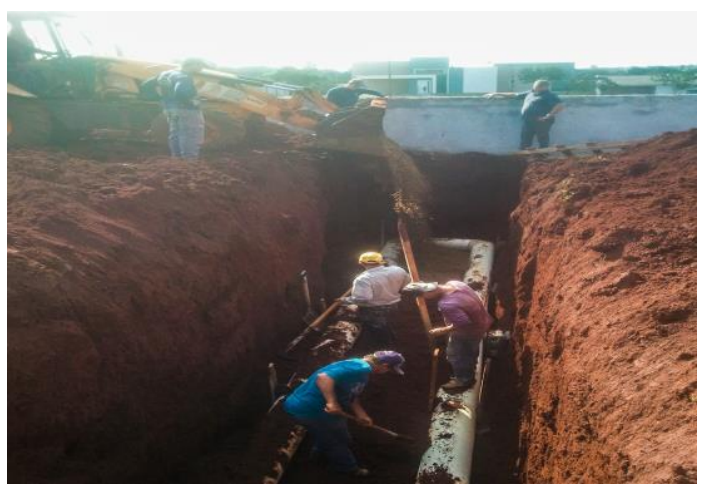

Fig. 6. Implementation of the geothermal system in loco.

The system has Sicflux Ar-kit model 11 fan with exhaust capacity of $2 \mathrm{~m}^{3} /$ minute and a $0.4 \mathrm{~mm}$ mesh screen installed in the air intake in order to prevent the entrance of insects and rodents.

\subsection{Data collection}

In order to collect the data regarding external air temperature, air temperature at the entrance and exit of the system, 3 units of HOBO U10-001 Data logger devices were used, set up to register the temperature every 10 minutes synchronously.

Data analysis was done using Microsoft Excel software. Information was collected from July 29 to September 1 of 2016, a total of 34 days.

The lowest temperature of the period was recorded on $8 / 22 / 2016$ and the highest temperature on $08 / 27 / 2016$. There were 5002 inlet and outlet air temperature records compiled in the period.

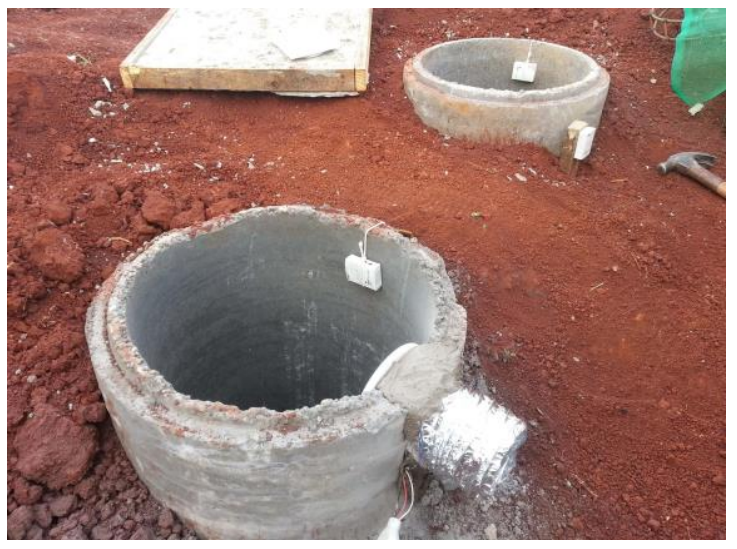

Fig. 7. Installation of HOBO U10-001 devices.

\section{Results and discussion}

According to ASHRAE Standard 55-2010, the comfort zone temperature for September would range from $21^{\circ} \mathrm{C}$ to $26.5^{\circ} \mathrm{C}$. A comparison was made with the data obtained to identify the percentage of temperature that was within the ASHRAE parameters. 
The average temperature obtained in the period was $18.32^{\circ} \mathrm{C}$. The maximum and minimum peaks were analyzed, being $35.54^{\circ} \mathrm{C}$ the maximum temperature and $2.84^{\circ} \mathrm{C}$ minimum.

Table 2 shows the comparison between the external air temperature and the air preheated / cooled by the geothermal system during the whole analyzed period.

Table 2. General data analysis table.

\begin{tabular}{|c|c|c|}
\hline $\begin{array}{c}\text { Temperature } \\
\text { range }\end{array}$ & $\begin{array}{c}\text { Air inlet } \\
\text { temperature (\%) }\end{array}$ & $\begin{array}{c}\text { Air outlet } \\
\text { temperature(\%) }\end{array}$ \\
\hline Below $21^{\circ} \mathrm{C}$ & 74 & 72 \\
\hline $\begin{array}{c}\text { Between } 21^{\circ} \mathrm{C} \\
\text { and } 26,5^{\circ} \mathrm{C}\end{array}$ & 15 & 27 \\
\hline Above $26,5^{\circ} \mathrm{C}$ & 11 & 2 \\
\hline
\end{tabular}

According to data collected during the period, $15 \%$ of the outside air temperature was inside the comfort zone, and at the exit of the system, after the temperature change, $27 \%$ of the air conditioning was in the comfort zone.

It was found that the system showed an average air cooling of $6^{\circ} \mathrm{C}$ on days when the outside temperature exceeded $33^{\circ} \mathrm{C}$, and a mean of $10^{\circ} \mathrm{C}$ heating on days when the outside temperature was below $6^{\circ} \mathrm{C}$.

Throughout the analyzed period, the system was able to promote an increase in the air outlet temperature from $2^{\circ} \mathrm{C}$ to $11.3^{\circ} \mathrm{C}$ in $40 \%$ of the time when internal air heating was necessary. For cooling, the drop in the outlet temperature between $2^{\circ} \mathrm{C}$ and $8^{\circ} \mathrm{C}$ represented $13 \%$ of the period. Which means that in $53 \%$ of the time, the air was cooled by at least $2^{\circ} \mathrm{C}$ for more or less.

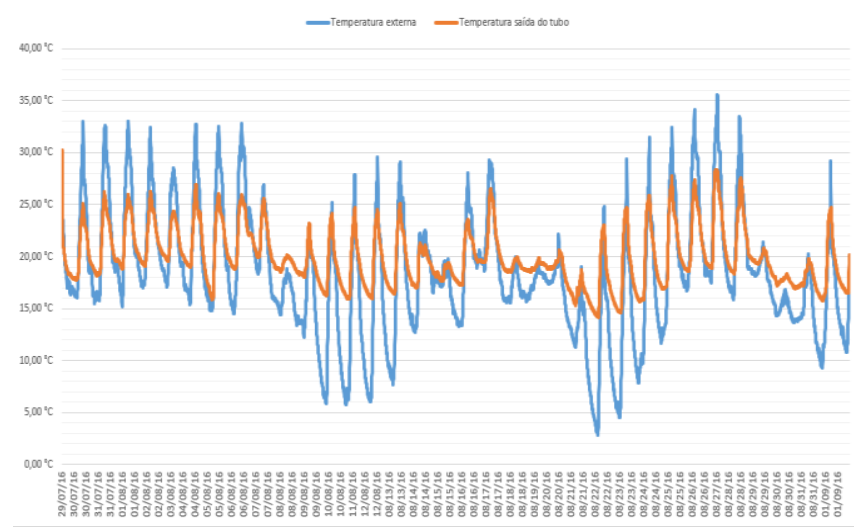

Fig. 8. Graph of inlet and outlet temperatures of the system in the total period.

The warmest day recorded showed $16 \%$ of the external air in the comfort zone and $33 \%$ of the air acclimated by the system was in the comfort zone, and the cooling peak happened at $1: 40$ in the afternoon when the outside temperature was at $35.34^{\circ} \mathrm{C}$ and the outlet air at $28.16^{\circ} \mathrm{C}$, a total of $7.28^{\circ} \mathrm{C}$ cooled down.

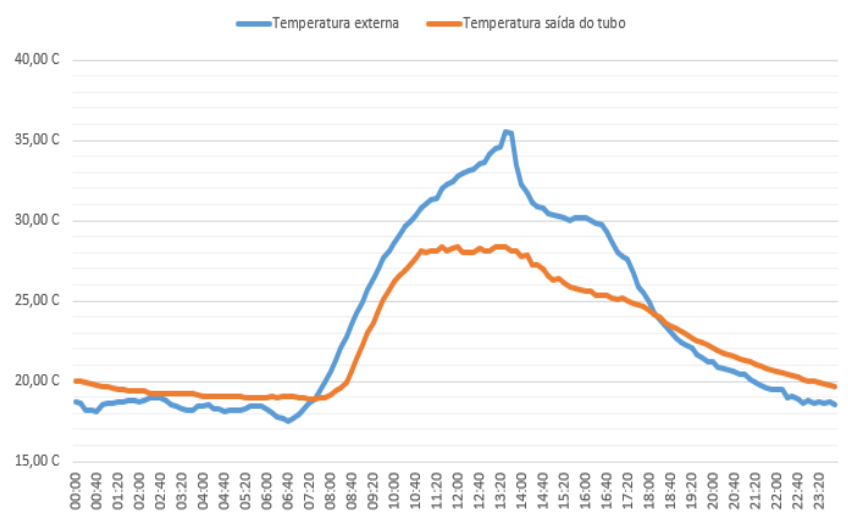

Fig. 9. Graph of inlet and outlet temperatures of the system on 08/27/2016.

The coldest day registered a result of $4 \%$ of the external air in the comfort zone and $19 \%$ of the air warmed by the system was in the comfort zone. The peak of heating happened at 06:50 in the morning when the outside temperature was in $2.84^{\circ} \mathrm{C}$ and the outlet air at $14.23^{\circ} \mathrm{C}$, a total of $11.39^{\circ} \mathrm{C}$ heated.

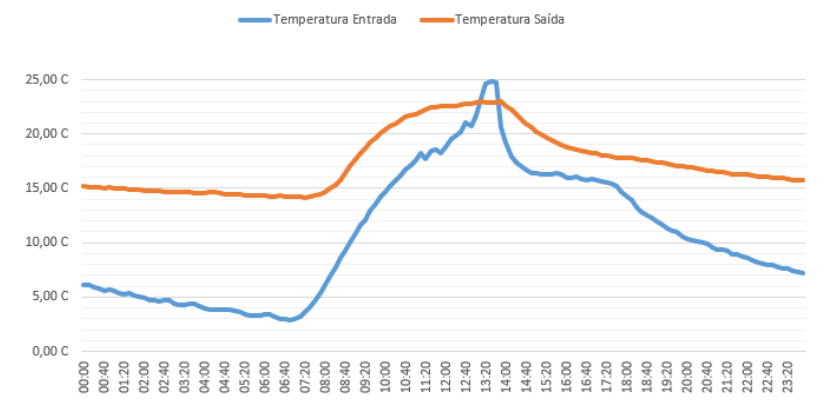

Fig. 9. In and out temperatures graphic of 08/22/2016.

With this it is possible to conclude that the system can be used to reduce mechanical acclimatization, and, also to assist the pre-acclimatization of the air passively before being mechanically done.

\section{Conclusion}

Searching for more efficient approaches regarding acclimatization in hot and humid climate regions assists professionals and institutions interested in reducing the need for energy use and mitigating the environmental impacts resulting from its production. Thus, this study aimed to study the possibility of using a system of earth-to-air heat exchangers as a strategy for the natural ventilation of hot and humid environments.

The study identified the potential of acclimatization through the soil of the city of Foz do Iguaçu, both to preheat and pre-cool the air. During the data analysis, it was possible to verify that an earth-air heat exchanger system is feasible when it comes to reducing thermal loads of mechanical acclimatization and reducing the energy consumption in regions of hot and humid climate with thermal variation of the soil, with capacity of a $12 \%$ increase in the air comfort zone and a monthly air conditioning gain of $2^{\circ} \mathrm{C}$ or more in 
$53 \%$ of the period, with heating up to $11^{\circ} \mathrm{C}$ and cooling up to $8^{\circ} \mathrm{C}$.

\section{References}

1 M. Wassouf, Da Casa Passiva à Norma Passivhaus: a arquitetura passiva em climas quentes, GG, 143 (2014)

2 M. M. E. Brasil, B. E. N. 2018, EPE, (2018).

3 R. Lamberts, L. Dutra e F. O. Pereira, Eficiêcia Energética na Arquitetura, 366 (2014).

4 N. Lechner, Heating, Cooling, Lighting, W., 730, 4 (2015).

5 J. V. Lengen, Manual do arquiteto descalço, LA, (2004).

6 D. B. Musskopf, Estudos exploratórios sobre ventilação natural por tubos enterrados, (2006).

7 E. C. Souza, Aplicabilidade de sistemas de ventilação com permutador de calor ar-solo no clima português, UM, (2014).

8 J. Mathur, R. Misra, V. Bansal, G. Agarwal, Thermal performance investigation of hybrid earth air tunnel heat exchanger, EB, 531-535, 49 (2012).

9 S. R. P. França, Simulação visando a ventilação de residências através de tubos enterrados, UFRGS, (2011)

10 A. R. Pereira, Agrometeorologia - Fundamentos e Aplicacoes Práticas, 478 (2002)

11 I. Fonseca, T. Casalini, F. Tucci e A. Battisti, XV ENTAC, 538 - 546 (2014)

12 R. J. L. V. CRUZ, Utilização da Energia Térmica do Solo para Climatização de Edifícios, UA, 77 (2013)

13 H. Bulut, Y. DEMIRTAŞ, R. KARADAĞ e I. HİLALİ, 8th M. C. H. V. A. C. C., 1-8, (2015)

14 I. Fonsecca, F. Tucci e A. Battisti, XIII ENCAC, (2015) 